\title{
Muslim Minority in Greek Historiography: A Distorted Story?
}

\author{
Dr Stefanos Katsikas
}

\begin{abstract}
This paper provides a bibliographical review of the major academic works which have been published or translated into Greek and deal with the minority life of Muslims who have lived in Greece since the early 1830s. The paper focuses on the methodological approach of these works, the time of their publication and the research fields which they cover or disregard. It argues that by the end of the Cold War Greek academic works on the subject are highly influenced by the climate in Greco-Turkish relations. They remain silent about Muslim populations who lived prior to 1923 in the country and focus on the Muslims of western Thrace, the minority life of whom they portray a distorted picture. This has started to change since 1989, but there is still a long way to go until Greek academia overcomes its biased, emotional and politicallyinfluenced modus operandi on the subject and undertakes a more dispassionate approach.
\end{abstract}

\section{I ntroduction}

According to the 1951 census, the last census the Greek government published official date indicating the religious affiliation and the mother tongue of the population of Greece, Muslims constitute the largest religious minority in Greece. ${ }^{1}$ Their numbers since changed, especially after 1989 with the influx of Muslim immigrants from neighbouring Balkan states, the Middle and the Far East, who have come to Greece seeking work and a temporary or permanent settlement away from the political and economic hardships of their respective countries. The exact number of these immigrants is difficult to calculate, but this is nonetheless beyond the scope of this paper. The focus of this paper are Muslims who became 'citizens' of the Greek state through its territorial expansion from the time of its establishment as a new nation state in the 1830 s to 1947 , the year of its last territorial expansion the annexation of the Dodecanese insular complex. With the exception of the Albanian-speaking Muslims of Northwestern Greece, known as Çams, who were regarded by the Albanian authorities as ethnic

$1 \quad 112,665$ people (or 1.4\%) of the recorded population reported their religious affiliation as Muslim and the vast majority of them live in western Thrace. 
Albanians and thus sought to offer political protection to them, the rest of the Muslims in Greece have been seen as a kin religious group by the Ottoman Empire and later the Republic of Turkey. Istanbul - and later Ankara - sought to protect the latter group's minority rights through bilateral agreements with Athens and in various international treaties.

From the Muslims who have lived in Greece since the 1830s, all that remains today is a sizeable Muslim community that lives in Western Thrace - in the northeast of the Greek mainland - as well as less than 5,000 people who live on the islands of Rhodes and Kōs. ${ }^{2}$ A more precise estimation of western Thrace Muslims is a complicated issue due to the lack of official data, but some approximations which are based on the very rarely broken secretiveness of Greek officials put the number at around $120,000 .^{3}$ They are divided into three categories, according to their descent: a) Turkish origin (Tourkogeneis), b) Slav-speaking (Pomaks) and the Roma (Tsigganoi, Athiganoi, Katsiveloi or Gyftoi).

The Muslims of Thrace and the Dodecanese Islands do not constitute the only case of Muslim population ever to have lived in Greek territory. In the aftermath of the 1821 national revolution, a small but undetermined number of Muslims lived in the newly independent Greek Kingdom. ${ }^{4}$ Their number increased with the annexation of the region of Epirothessaly in 1881 entailed that around 40,000 Muslims who lived in that region became subjects of the Greek king. ${ }^{5}$ In the aftermath of the Balkan Wars in 1912-1913 and the First World War more than half of a million Muslims came under the authority of the Greek state in the annexed regions of Greek Macedonia, Thrace (western and eastern), the region around Smyrna (Izmir in Turkish) in Asia Minor and most of the islands of the Aegean Sea, including Crete. ${ }^{6}$ All these people left Greece as a result of forced and voluntary emigrations, the Greco-Turkish compulsory population exchange of 1923 and retaliatory measures taken by the Greek state authorities and paramilitary organizations. The Albanian-speaking Muslims of

\footnotetext{
2 Meinardus, 2002, p. 84

Alexandrēs, 1991b, p. 524 . .

Popovic, 1986, pp. 115-6.

Ibid., p. 117-123. Epirothessaly is a technical term used by historians to refer to the Ottoman regions which became part of the Greek state with the Greco-Ottoman treaty of Istanbul on 2 February 1881 and does not correspond to any administrative unit of today's Greece under this name. These regions correspond to Greece's administrative district which is today known as Thessaly, without the region of Elassona, and part of the administrative district of Epirus which corresponds with today's prefecture of Arta.
}

$6 \quad$ Popovic, 1986, pp. 123-151, 
Thespōtia (north-western Greece), known as Çams, although exempted from the 1923 obligatory Greco-Turkish population exchange, left Greece due to retaliatory measures taken by paramilitary organizations and guerrilla forces, which used the cooperation of many of the Çams with the Italian and German occupation forces during the Second World War as a pretext to ethnically cleanse the region from populations which were seen as non-Greek. ${ }^{7}$

The subject of Greek minorities has always been a hot issue in Greek politics and public life. This sensitivity should be seen as part of the Greek-Turkish cluster of problems, which have often brought Athens and Ankara to the brink of war. The Muslim minority of western Thrace falls into that cluster and because of this it has been highly politicised by the Greek political and cultural elites. For the majority of Greeks, the Muslims of western Thrace are seen as a Trojan horse, an ethnically and religiously alien group, akin to the country's perceived biggest national enemy, namely Turkey, which could in the long term question the state sovereignty in that region.

Greek historiography shares responsibility for this attitude. By 'Greek historiography' the paper refers to published monographs, academic articles and research papers written in the Greek language by academics working in academic institutes and NGOs in the Hellenic Republic. Of course, there is much published work on the issue in other languages by non-Greek as well as Greek scholars. ${ }^{8}$ However, the focus of the discussion of this paper will be academic works on the Muslims of Greece which have been written or translated into Greek. This is because the paper seeks to review the various narratives produced on the subject by the Greek academic elite, including those foreign narratives to which the native academic community showed an interest and thus have been translated into Greek. It is assumed that the attitudes towards the Muslim minority by the Greek political elite and the public shape and are shaped by these narratives in a dialectical way and the paper attempts to explore what these narratives are, how they were developed and what factors influenced their development.

Overall the relationship between the Greek national historiography and the Muslim Minority has been problematic in the sense that most of

7 Manta, 2004, pp. 133-198.

$8 \quad$ Published academic works on the issue which have been written by Greek and non-Greek academics in languages other than Greek and have been translated into Greek also fall within the scope of analysis of this paper. 
the published academic works on the subject have been influenced by the current political climate in Greco-Turkish relations. The argument of this paper focuses on the following three topics which are examined below: 1) the timing and the political context in which academic works on the subject are published; 2) their methodology and writing style; 3 ) the research fields which have been explored so far.

\section{Timing of Publications}

Prior to 1989 the number of published works on the Muslims of Greece was relatively small. The majority of publications on the subject mainly occur in the late Cold War and early post-Cold War periods. This is exemplified by the exhaustive bibliographical overview of Foteine Asimakopoulou and Sevastē Christidou-Lionarakē. ${ }^{9}$ From the approximately 164 Greek titles provided on the authors' bibliographical lists with direct or indirect references to the Muslim minority of Greece, only 55 of them (34\%) were published before 1989 From the 55 titles published before 1989, around 18 of them (11\%) were translated academic works of non-Greek academics, mainly Turks working in Turkish academic institutes, which leaves the number of Greek published works by Greek academics working in Greece at 37 $(22.7 \%) .{ }^{10}$

The main explanation for this proportional discrepancy before and after 1989 is related to the current climate in Greco-Turkish relations and the way in which that climate has affected the relationship between the Muslim population and the Greek state. Thus, following the ethnic conflicts of the 1950s, 1960s and early 1970s between Greek and Turkish Cypriots in Cyprus which led to the 1974 Turkish invasion of the island and the occupation of almost $40 \%$ of its territory since then, Greek-Turkish relations entered a period of prolonged tension, with both states reaching the brink of war twice in March 1987 and in January $1996 .{ }^{11}$ The tension regarded a series of bilateral issues, including the respect of the minority rights for Western Thrace Muslims in line with the provisions of bilateral as well as international treaties such as the 1923 Lausanne Treaty. In this context, the affairs of the

$9 \quad$ Asimakopoulou \& Christidou-Lionaraki, 2002.

10 The numbers provided are only indicative and attempt to show the disproportionate number of published academic works prior to and after 1989. Original works, such as treaty documents - i.e. the Lausanne Treaty - or those referring to the Greek Foreign Policy and Greek-Turkish relations, were exempted from the calculations provided. Also, academic works published in languages other than Greek have not been included in the above counting, because, as it has been already explained, these works fall beyond the research scope of this paper.

11 Alexandrēs, 1991b, pp. 497-523; Coufoudakēs, 1991, pp. 222-27; Tsitsopoulos \& Veremēs, 1991, pp. 187-191; Rozakēs, 1991. 
Muslims in Thrace start becoming the focal point of the political and academic debate in Greece.

In April 1990, the conservative party New Democracy came into power and about a year later its government under the premiership of the party's leader, Kōnstantinos Mētsotakēs, tried to reform the legal framework which ruled the minority status of the Muslims of Greece by introducing the Law 1920/1991 which regulated the appointment of Muslim religious leaders, muftis. The law was not received well from members of the minority elite and a debate followed with the participation of members of the Greek academic community, which in turn resulted in the boost in Greek published works with reference to Western Thrace Muslims. Thus, works such as that of Georgoulès, Soltaridēs and Tsitselikēs which were published after the introduction of Law 1920/1991 and attempted to situate the 1991 legal reforms on the status and duties of the Western Thrace Muslim religious leaders, known as muftis, into a broader historical framework with the first two even providing examples of the status and duties of muftis elsewhere in the World. ${ }^{12}$

Besides monographs and academic articles, academic debate on Western Thrace Muslims has been also conducted through the press, magazines and the mass media and in this way it reached the wider Greek public. Thus, a number of articles by Greek academics and specialists such as Alexēs Alexandrēs, Kōnstantinos Vakalopoulos, as well as others have often appeared in the Greek press and magazines. ${ }^{13}$ In addition, at around the same time, in 1993, the first well-detailed bibliographic guide on Western Thrace, with the inclusion of titles relating to the Muslim minority of the region was compiled by Kotzagiōrgē Xanthippē and Panayotopoulou Anna and was published through the Foundation for the Study of Aimos (Balkan) Peninsula, commonly known as I.M.X.A, in Thessalonikē. ${ }^{14}$

The increasing academic focus on the Muslim Minority in the 1980s and the post-1989 period can be also explained by a well-established view among academic circles in Greece and abroad that the end of the Cold War would result in regional instability in Eastern Europe and the Balkans, with the minority issues being a major factor of this instability. ${ }^{15}$ This view was corroborated by the ethnic conflicts in the neighbouring Yugoslavia, the disturbed state-minority relations in

\footnotetext{
12 Georgoulēs, 1993; Soltaridēs, 1997; Tsitselikēs, 1999.

13 Alexandrēs, 1981; Vakalopoulos, 1990.

14 Kotzagiōrgē \& Panayotopoulou, 1993.

15 Perrakēs, 1993
} 
Bulgaria due to Bulgarian communist regimes' attempts at the end of the 1980 s to forcibly change the Muslim names of the country's Muslims with Bulgarian ones as well as the disturbed state-minority relations elsewhere in the Balkans. ${ }^{16}$

Within this context a number of academic works such as those of Koppa, Rozakēs, and others discuss the significance of the minority factor in the domestic and regional security of Southeastern Europe and refer to political measures taken by international actors such as the European Union (EU), the USA, NATO and other international organizations, which improved or undermined inter-ethnic as well as state-minority relations and thus the political, economic and social stability of the region. ${ }^{17}$ Other works such as those of Tsitselikēs and Christopoulos refer to the issue of human and minority rights protection in Greece, including those of the country's Muslim minority, with reference to provisions in the international law, the European legal framework and social practice elsewhere in Europe. ${ }^{18}$ Scholars such as Troubeta, Tsibiridou, and Petrakē explore issues such as the Greek national ideology, national identity construction, bilingualism, ethnic as well as labour relations, sexuality, gender identities and roles inside the family and the local lives with reference to the Muslim minority of Western Thrace. ${ }^{19}$

The introduction of a relatively proportional electoral law on 10 April 1989 which allowed the election of a member of the Muslim minority in Western Thrace (Ahmet Saadik) as an independent Member of the Greek Parliament (MP) - i.e. without affiliation to any of the existing parliamentary political forces - in the general elections of 18 June 1989, was another reason which led Greek academics to focus on the Muslim minority affairs in the post-Cold War period. This is because Ahmet Saadik, and his colleague Ahmet Phaikoglou, who was elected as the second independent Muslim MP in the general elections of April 1990, raised insistently and openly issues such as the violation of Muslim minority rights by the Greek state and local authorities in Western Thrace, the right of those minority members who wished to call themselves Turks to be allowed by the authorities to do so and many others, which had been taboo subjects by the majority of Greeks until then. Within this context and possibly influenced by the parliamentary representation of Muslims elsewhere in the Balkans, works such as those of Dōdos and Nikolakopoulos were published

\footnotetext{
$16 \quad$ Poulton, 1993; Clayer, 1997.

$17 \quad$ Koppa, 1997; Rozakēs, 1994.

18 Tsitselikēs \& Christopoulos, 1997.

19 Troubeta, 2001; Tsibiridou, 1995-1996; Petrakē, 1997.
} 
which analyse the electoral behaviour of the Muslim minority in Western Thrace: ${ }^{20}$ the former in comparison to the electoral behaviours of religious and ethnic minorities in Bulgaria and Albania, while the latter its electoral behaviour from 1923 to 1955.

Two publications, one by the Centre for the Study of the Greek Society at the Academy of Athens and another one by Lois Lambrianidès point to the economic underdevelopment of the region and its economic and social effects on Muslims, ${ }^{21}$ including those living inside the zone of military surveillance which the Greek state authorities imposed from 1936 to 1995 in the region. ${ }^{22}$ Those publications were conducted with reference to political measures taken by the then PASOK government which aimed at relaxing the restrictive measures of the Muslims in Thrace and culminated in the abolishment of the zone of military surveillance in 1995.

The deterioration of Greek-Turkish relations in the 1980s and most of the 1990s has dramatically increased the number of Greek academic works on the Muslims of Greece and led to the appearance of a number of publications which approach the subject through a narrow nationalistic prism. Their aim is to alert the Greek state authorities and the public about the changing political, economic and social state of the minority through a more active political involvement by Turkey into minority affairs. Works such as those of Gerondopoulos, Kēpouros, Magriotēs, and many others fall into this category. ${ }^{23}$

From the 1980s on, the academic landscape in Greece started to change so that in the 1990s it was quite different from how it had been in the past. An increasing number of young scholars with postgraduate degrees from Western universities are taking posts in Greek academic institutes. They have introduced new fields to the Greek academia such as social history, anthropology, the study of identity formation, human rights, gender studies and others. They use the Muslims of Western Thrace as their case study. A number of scholars mentioned above such as Assēmakopoulou, ChristidouLionarakē, Tsitselikēs and others fall into this category.

\footnotetext{
20 Dodos, 1994; Nikolakopoulos, 1990-91.

21 .Academy of Sciences, 1995; Lambrianidēs, 1997.

22 The aim of the imposition of such a zone was to restrict the contacts between the Muslims of Greece with those in Southern Bulgaria in order to prevent any ideological contamination of the former by the latter which might lead to the development of a sound anti-Greek ethnic identity that could encourage secessionist political movements.

23 Gerondopoulos, 1993; Kēpouros, 1989; Magriōtēs, 1995.
} 
Greek-Turkish relations do not seem to influence academic publications only after the 1980s. They did so to the scarce amount of publications which appear on this subject before the 1980s. Andreadēs's seminal work $\bar{E}$ Mousoulmanikē Meionotis tēs Dytikēs Thrakēs (The Muslim Minority in Western Thrace), which discusses the life of Muslims in Western Thrace during the interwar period as well as their relations with the Greek and Turkish state authorities, was published in Thessalonike in 1956, about a year after the independence movement in Cyprus and the September 1955 pogroms against the Greek population in Istanbul. In the introduction, the author justifies his decision to write this book as follows:

When due to the Cyprus issue, the demagogy of Turkish newspapers in Istanbul regarding the living conditions of the Muslims in Western Thrace began, [...] I decided to write (...) a special essay. ${ }^{24}$

The timing of the publication of Andreadēs's work is not unique. For example, Bekiaridēs's work was published in 1973 during a period of ethnic conflict in Cyprus and increasing tension in Greek-Turkish bilateral relations. ${ }^{25}$ Six years earlier, in 1967, the work of another Greek scholar, Economopoulos, was published in French. ${ }^{26}$ By the same token, Eleftheriadēs's work and some others that followed after this occurred at a time in which Greece had doubled its territory after the end of the two Balkan and the First World Wars and, as a result of this, a great number of Muslims became subjects of the Greek Kingdom. ${ }^{27}$

\section{Methodology and Writing Style}

Most Greek published work with reference to the Muslims of Greece approaches various aspects of the life of Muslims within the narrow prism of Greek-Turkish relations. Many of these works are not dispassionate academic works whose task is to shed light on unknown sides of the minority political, economic, social and cultural life, but their common denominator is to stress that Muslims of Greece enjoy all minority rights they should, or that they enjoy much more freedoms and better living conditions than those of the Greek Orthodox in Turkey. This is done to either support existing minority policies on the part of the Greek authorities or to criticize them for the

Andreadēs, 1956, pp. 7-8.

Bekiaridēs, 1973

Economopoulos, 1967.

Eleftheriadēs, 1913, 1915, 1917. 
allegedly excessive freedom they allow to the country's Muslims and thus do not reciprocate past and/or current tough minority policies towards the Greek Orthodox by the authorities in Turkey. This is not to say that there are no dispassionate academic works on the subject. On the contrary, there are, but these works have been mainly produced since the 1990s, by young academic scholars who have studied and spent part of their research abroad, mainly universities of Western Europe.

A good example that shows how Greek scholarly works on the Muslims of Greece are often academically non-dispassionate research products is Symeōn Soltaridēs' 1997 monograph, in which the author explains:

A proof of the political freedoms which the Muslim Minority of Western Thrace enjoys is that all its members participate, like ethnic Greeks, in the general and local elections. It is noteworthy that in 192819 out of 92 elected local leaders (mayors) in Western Thrace were Muslims..... On the contrary Turkey has violated the civil, political and economic rights of the Greek Orthodox in Istanbul and the islands of Imvros and Tenedos, by forcing the vast majority to leave these places without the existence of any bilateral treaty to rule any population exchange between the two states. ${ }^{28}$

Elsewhere in his book, Soltaridēs includes a section which discusses the way by which Muslim religious leaders are appointed in states where the majority of the population is Muslim, i.e. Jordan, Tunisia and Egypt, and comes to the point that: 'a proof that Ankara's accusations that the Greek state authorities interfere with the religious life of the Muslims in Western Thrace are totally unfounded because similar procedures of appointment of Muslim religious leaders to those of Greece existed elsewhere'. ${ }^{29}$ However, the author's argument at this point contradicts information provided elsewhere in the monograph, according to which the Greek law 586/1941, which is still in force today, provides that for the erection of mosques in Western Thrace, the Muslim minority authorities need the prior consent of the local Orthodox Metropolitan bishops, which is not the case in Jordan, Tunisia or Egypt, indicating that the Greek legal system provides for the interference of Greece's established Church, i.e the Christian Orthodox Church, with minority affairs. ${ }^{30}$

\begin{tabular}{ll}
\hline 28 & Soltaridēs, 1997, p. 86. \\
29 & Ibid., p. $97 \mathrm{ff}$ \\
30 & Ibid., p. 120.
\end{tabular}


Many of the Greek historiographical works on the country's Muslims are empirical analyses of events, religious as well as other institutions', and minority affairs which lack a theoretical framework and at points become too descriptive. In doing this, they follow a historiographical tradition in the country, which is met elsewhere in the Balkans and beyond, according to which a good historian should be in a position to provide much information on a subject with less analysis and without an argument, leaving thus the reader to reach his or her own conclusions. Scholarly works which employ certain theoretical tools to be thoroughly explained by scholars are few and appear after the 1990s. For example, in her 2001 monograph Troubeta employs existing theoretical works on identity and minority building and uses them in the case of the Pomaks and the Muslim Romas in Western Thrace in order to answer questions such as: how do the religious, national, linguistic and cultural factors on the one hand, and the social conditions on the other affect the way that the members of a minority define themselves and are defined by others? ${ }^{31}$

The terminology adopted by scholars when they refer to the Muslims of Greece is problematic and inadequately defined. With the exception of Turkish academic works which have been translated into Greek and refer to Western Thrace Muslims as a 'Turkish minority', or 'Turks of Greece', the majority of Greek academic works published by Greek scholars use the term 'Muslim minority' when they refer to the Muslims of Western Thrace. This is because this is a politically correct term which is accepted by the majority of the Greek political elite and the public and is mentioned both in the Lausanne Treaty of 1923 and the 1923 Greek-Turkish Convention which determined the rules for the obligatory population exchange. ${ }^{32}$ The only exception was during the early Cold War years when the Greek authorities followed a policy of purposeful Turkification of the minority in which the Muslims of Western Thrace were then called 'Turks of Thrace' or the 'Turkish minority of Thrace'. ${ }^{33}$

Many Greek academic works argue that the Muslim minority of Western Thrace consists of three ethnic components, namely those of Turkish origin (sometimes referred to as Turkish-speaking Muslims),

31 Troubeta, 2001, pp. 17-24.

32 According to a decision made by the Magistrate Court of Komotēnē on 20 March 1986, which was also upheld by the Athens High Court on 28 June 1987, the adjective 'Turkish' was prohibited from being used to describe the members of the western Thrace Muslim minority or any association and organisation of any kind with reference to the minority. Poulton, 1993, p. 186.

33

Andreadēs, 1956, p. 4. 
the Pomaks and the Romas (Athigganoi or Tsigganoi) but only a few of those works define these terms and when they do the definition is problematic. The term 'Muslims of Turkish origin' or 'Turkish-speaking Muslims' which are often given to the majority ethnic group of the Muslim minority are problematic because the first is based on genetic criterion and thus it is difficult to determine who is of Turkish origin and why, and who is not and why not, while the second refers to the language, which, due to the educational policies followed by the Greek authorities after 1923 as well as the inter-ethnic and inter-cultural contacts among all ethnic elements of the minority, Turkish is a widely spoken language and is used even by Pomaks and Romas. The term Pomak is problematic in the sense that it is a label which has been mainly decided and given by others to that particular ethnic group and not by the members of this ethnic group themselves. Similar problems occur with the definition of the third ethnic group. Terms like Gypsies, Athigganoi, Tsigannoi are avoided by the members of that ethnic group because they are pejorative. Thus many Muslim Romas follow the example of the Pomaks and are self-defined as Muslim Turks, which makes the issue even more complicated.

The first serious academic attempt to deal with issues of self-definition by the members of the Muslim minority as well as of their definition by members outside the minority is made by Troubeta in her 2001 monograph. ${ }^{34}$ In this monograph the author discusses all the problems regarding definitions of the three ethnic groups of Western Thrace Muslims, which have already been discussed, while the concepts 'Minority Turks', 'Pomaks' and 'Athiganoi' which are adopted by convention, are problematic, by the author's admittance. ${ }^{35}$

With regards to the writing style, with the exception of the few dispassionate academic works which have been published since the end of the 1980s the majority of Greek publications on the subject by the end of the 1980s and many of those after that time adopt a militant, aggressive writing style. Their analyses are often emotionallydriven and discuss aspects of the Muslim minority life in Western Thrace in comparison to how these issues are dealt with by the state authorities in the Republic of Turkey. The reference points of these works are the bilateral Greek-Turkish agreements, especially the 1923 Lausanne treaty, and not international agreements, treaties and conventions, and policies of international organisations such as the UN, the EEC/EU, CSCE/OSCE to which Greece also participates. The same

$\begin{array}{ll}34 & \text { Troubeta, } 2001 . \\ 35 & \text { Ibid., pp. 17-24. }\end{array}$ 
pattern is followed by Turkish works translated into Greek such as those of Aydinil, Kadurgali and others to which this paper refers elsewhere and whose writing style is equally militant and aggressive as that of their Greek colleagues in order to justify arguments set forward by the Turkish authorities that the minority rights of the Muslims of Western Thrace have been violated by the Greek authorities.

\section{Fields of Research}

\section{The Appearance of Muslim Groups}

One of the very few Greek scholars who have studied the issue of Islamisation of various non-Muslim religious groups in areas which today constitute part of Greece is Zeginēs. His case study was the region of Western Thrace. ${ }^{36}$ The author argues that conversion on Islam by local Christians in Thrace was mainly conducted through Bektashism, a popular heterodox Islamic movement which combined elements of the formal Sunnite Islam and other religions, including Christianity. The religious leaders of Bektashism, known as dervishes, hold a strong appeal to the locals, who, due to tough policies on Islamisation undertaken by the Ottoman authorities, preferred to convert to an Islamic movement which preserved elements of their own religion rather than to accept the official Sunnite Islam.

The majority of Greek academic works on the Muslims of Greece refer to the post-1923 period. For the period up to the Second World War the most detailed academic studies on the subject are the works of two non-Greek scholars such as Tchemalovitch and Özgüç. Both of these scholars provide detailed information on the legal status as well as the political and social life of the Muslims of Western Thrace, including the powers of the muftis, Muslim education and others. ${ }^{37}$ Andreadēs's 1956 monograph covers the same issues as the works of Tchemalovitch and Özgüç, but in a way which provokes reaction among academic circles in Turkey which claimed that many of the historical facts presented in the monograph were biased. Thus, in response to this work, a series of Turkish publications took place at around the same time which discussed aspects of the life of Western Thrace Muslims prior to as well as after the Second World War. ${ }^{38}$ In certain Greek academic journals such as Valkanikē Vivliografia (Balkan

$36 \quad$ Zeginēs, 1988.

37 Tchemalovitch, S.A., 'Les Musulmans en Grèce' (The Muslims in Greece), L' Europe de l' Est et du Sud-Est, Vol. 3, No. 3, 1933 and Özgüç, A., Bati Trakya Türkleri (The Turks of Western Thrace), Istanbul: Er-Tu Matbaasi, 1974, as they are cited by Popovic, 1986.

$38 \quad$ Aydinli, 1973. 
Bibliography), Deltion Tourkikēs Vivliografias (Bulletin of Turkish Bibliography) and Valkanika Symmeikta (Balkan Mixted), a number of Greek translations of Turkish academic works with reference to Western Thrace Muslims have been published. Most of these translations come from works which were originally published in the Turkish academic journal Türk Kültürü (Turkish Culture). A special issue by the Türk Kültürü (Vol. 14, 1976) on the life of Greece's Muslims was translated in Greek and published in Valkanike Vivliografia (Vol. 5, 1979), including a review of T. Kadurgali on Andreadēs's 1956 monograph which is published in that issue. ${ }^{39}$

\section{Various Ethnic Components of Muslims in Greece}

Zeginēs sheds light on the historic origin, religious beliefs and customs of Muslim Romas in Western Thrace. ${ }^{40}$ The author adopts the theory provided by scholars such as Lithoxoou according to which this ethnic group originated in India, settled in the region of Western Thrace during the Byzantine period and was Islamised in the Ottoman times. ${ }^{41}$ Troubeta discusses how the Muslim Romas and Pomaks in Western Thrace are ethnically and religiously self-defined, how they are seen by the Greek Orthodox and Muslims of Turkish origin in the region and how they have been treated by the Greek and Turkish authorities as well as by members of the Greek Orthodox and Muslim minority local elites in different phases of the Greek-Turkish dispute since the 1980s. ${ }^{42}$

The origin of the Pomaks has been an apple of discord for Greek, Turkish and Bulgarian historians since the beginning of the $20^{\text {th }}$ century. For Bulgarian historians they are Islamised Bulgarians who adopted Islam during the Ottoman period. Turkish historians see Pomaks as Bulgarised Turks. Finally, Greek historians see them as indigenous Islamised people, descendants of ancient Thracians - the latter are viewed as ancient Greek tribal groups. The Greek scholar Xaralambidēs provides a review of the dominant views by Greek, Turkish and Bulgarian historians regarding the origin of the Pomaks which is published in the Greek academic journal Thrakikē Epetērida (Thracian Bulletin). ${ }^{43}$

\footnotetext{
$39 \quad$ Kadurgali, 1979.

40 Zeginēs, 1994

41 Lithoxoou, 1991a, 1991b.

42 Troubeta, 2001.

43 Xaralambidēs, 1985-86.
} 
Indeed, the majority of Greek works have attempted to trace the relationship between the Pomaks and ancient Thracian tribes in the region in an effort mainly to disprove Bulgarian claims that Pomaks are Islamised Bulgarians. These works have been influenced by the political climate of the time. Recognising the Pomaks as a Bulgarian ethnic group was viewed as paving the way that the Bulgarian communist authorities in the future would claim political, cultural and other rights on that ethnic group. A number of works have been published since the early Cold War years which argue that the Pomaks are related to ancient Thracian tribes and therefore are not Bulgarian. Among those one could mention the works of Papachristodoulou, Xyrotyrēs, and others. ${ }^{44}$

The deterioration of Greek-Turkish relations in the late 1970 s and during the 1980s and 1990s was a turning point in the Greek published works with reference to the Pomaks. While until then Greek academic works emphasised the non-relation between the Pomaks and Bulgarians, Turks are now added to the picture and the Pomaks are increasingly presented as a suis generis ethnic group with no ethic relation to either the Turks or the Bulgarians. This is due to the fact that, partly to please the Turkish authorities and not undermine the Greco-Turkish rapprochement in the interwar period and the early post-Second World War years and partly to corrupt any existing cultural ties between the Pomaks and the Bulgarians, the Greek authorities followed a policy of Turkification of the Pomaks. ${ }^{45}$ Their common religious background with the other Muslim minority groups was overemphasised. They were encouraged to speak Turkish and study in the minority schools whose curriculum provided only for the teaching of Turkish and Greek languages and the textbooks used for the Turkish language were printed in Turkey and imported and distributed to minority pupils following their approval by the Greek government. ${ }^{46}$

Within this context, Papathanasē-Mousiopoulou employs a series of historical sources in order to argue that Western Thrace Pomaks are a suis generis ethnic group which speaks a Bulgarian dialect, practices Islam and originates from ancient tribal groups living in the region. ${ }^{47}$ The anthropological works of Tsiribidou and Efstratiou as well as the

\footnotetext{
$44 \quad$ Papachristodoulou, 1947; Xyrotyrēs, 1976.

$45 \quad$ Voss, 2007, p. 185.

46 The 1932 Greek-Turkish agreement of friendship and non-aggression was still in force and bilateral relations between Greece and Turkey until the mid 1950s were relatively good. Alexandrēs, 1991b, pp. 69-172.

47 Papathanasē-Mousiopoulou, 1991, p. 229
} 
sociological work of Mavrogianēs show that the Pomaks constitute a unique ethnic group in the Balkans whose community, cultural and everyday lives include elements which are met in other ethnic and religious groups in the Balkans and others which are unique in that ethnic group. ${ }^{48}$

With reference to Muslim groups outside Western Thrace, Manta's monograph on Çams is worth mentioning. ${ }^{49}$ The monograph analyses the way in which historical developments in this ethnic group affected Greek-Albanian diplomatic relations during the first half of the $20^{\text {th }}$ century and discusses claims which are often raised by the Albanian state regarding the economic compensation which the Greek state authorities should pay to the Çams for the properties they left behind after their departure from north-western Greece. It provides a dispassionate analysis of the events during the Second World War and the Greek Civil War which led to the departure of Çams from Greece and moves away from biased Greek and Albanian academic works on the subject.

A number of academic works such as those of Ladas, Pentzopoulos, and others focus on the issue of the 1923 Greco-Turkish obligatory population exchange, primarily the diplomatic negotiations and legal documents of the population exchange, and to a lesser extent its impact on the societies of the two states. ${ }^{50}$ However, Greek academic research has shown little interest in Muslim groups who lived in Greece prior to 1923 such as those of Epirothessaly, Epirus, Macedonia and the islands of the Aegean, including Crete and the Dodecanese insular complex. There are few academic works on the Muslims of the postOttoman Balkans in the late $19^{\text {th }}$ and early $20^{\text {th }}$ centuries that make scrappy references to the Muslim communities of Greece. Most of these works belong to non-Greek academics and can be found in the bibliographic references of Popovic works. ${ }^{51}$

\section{Political Structures of Muslims in Greece}

Greek scholars such as Minaidēs, Georgoulēs, Tsitselikēs and others have researched issues relevant to the political organisation of the Muslims of Greece, such as the appointment of muftis, the election of Muslim community councils and their political powers. ${ }^{52}$ For the legal

\footnotetext{
48 Tsiribidou, 1985-1986, 1994, 1996, 1998, 2000; Mavrogianēs, 1982.

$49 \quad$ Manta, 2004.

$50 \quad$ Ladas, 1932; Pentzopoulos, 1962.

51 Popovic, 1986

52 Minaidēs, 1990; Georgoulēs, 1993; Tsitselikēs, 1999.
} 
framework of Greece's Muslims prior to 1923, Eleftheriadēs's research is the first of its kind and a reference point for most of the later academic works on the subject. ${ }^{53}$ Georgoulēs and Bekiaridēs focus more on the region of Western Thrace. ${ }^{54} \mathrm{~A}$ number of academic works discuss the existence of a civil society among Western Thrace Muslims. Tsibiridou, Kourtovik, and others shed light on Muslim civil associations during the 1980s and 1990 and show the decline of civic life among Western Thrace Muslims in those years. ${ }^{55}$

Nikolakopoulos is the first Greek scholar to examine the electoral behaviour of Greece's Muslims with reference to the country's general elections. ${ }^{56}$ His work focuses on Western Thrace from 1923 to 1939. The author argues that during the interwar period the Muslims of Western Thrace were represented politically through existing Greek political parties and that situation continued after the Second World War and throughout most of the Cold War years. ${ }^{57}$ The 1985 general elections, however, seem to be a turning point in the electoral behaviour of Greece's Muslims. This is because in those elections Western Thrace Muslims sought political expression though a political party named Eirēnē (Peace), which was religiously based and mainly represented the Muslims of Western Thrace. This pattern continues later with the foundation of the Muslim parties Embistosyne (Trust) in the constituency of Rhodopē, with the election of Ahmet Saadik in the general elections of June 1989, and Peprōmeno (Destiny) with the election of Ahmet Phaikoglou in the April 1990 general elections in the constituency of Xanthē.

\section{Inter-ethnic Relations}

Notaras portrays the Greek society as tolerant towards its religious and ethnic minorities, including the Muslims of Western Thrace. He explains this tolerance as the result of Greeks' long-standing experience with the multi-ethnic environments of the Roman, Byzantine and Ottoman Empires. Also, through their Greek Diaspora, Greeks have been in cultural contact with almost every religious, social and cultural formation in the world. ${ }^{58}$ Others scholars, however, such as Voulgarēs et al. argue that Greek society has not been as tolerant as scholars like Notaras have portrayed it. With reference to Western

\footnotetext{
$53 \quad$ Eleftheriadēs, 1913

54 Bekiaridēs, 1973.

55 Tsibiridou, 1995-1996; Kourtovik, 1997.

56 Nikolakopoulos, 1990-1991.

57 Dodos, 1994.

$58 \quad$ Notaras, 1995.
} 
Thrace, in particular, Voulgarēs et al. show that the Muslims of the region have been regarded as religiously, ethnically, and linguistically a non-Greek group and, because of this, they have often fallen victims of discriminatory policies by the Greek state and xenophobic treatment by the ethnic Greeks who live in the region. ${ }^{59}$

\section{Economic life}

There is little known about the economic life of Greece's Muslims prior to the 1923 Greco-Turkish obligatory population and those living outside Western Thrace after 1923. For example, academic works like Nakos's monograph mainly discuss land property issues, agricultural relations and problems being faced by the Greek state in the newly established Kingdom of Greece of 1832 and that of 1881 with the incorporation of Epirothessaly, due to the incorporation of parts of the Islamic Ottoman law into the Greek legal system. But Nakos's monograph does not discuss any other aspects of Muslims economic life beyond those which were just mentioned. ${ }^{60}$

As regards the Muslims of Western Thrace, there are references about their economic activities and situation in various published works. Andreadēs, for instance, refers to the economic life of Western Thrace Muslims in a section entitled Oikonomikē Katastasis (Economic Situation), while the following section discusses measures taken by Greek authorities to reconstruct the minority's economic life after the Second World War and the Greek Civil War. ${ }^{61}$ A study conducted by the Research Centre for the Greek Society of the Academy of Athens and published in 1995 refers to the geographical, social and economic isolation which characterises the life of Western Thrace Muslims. ${ }^{62}$ The research argues that Western Thrace Muslims are highly dependent on traditional agricultural activities, such as the cultivation of tobacco, cereals, corn, sugar-beets and others, which, together with their low educational level, makes them a marginalised social group in the region and dependent on external funding from West European Muslim migrants and Turkey. This situation renders them susceptible to political propaganda from Ankara. ${ }^{63}$

In his translated article published in Valkanike Vivliografia, Erdogan Merçil refers to the mechanisms used by the Greek junta regime to

\begin{tabular}{ll}
\hline 59 & Voulgarēs et al., 1995. \\
60 & Nakos, 1984 \\
61 & Andreadēs, 1956, pp. 21-44. \\
62 & Academy of Sciences, 1995. \\
63 & Ibid., p. 17-18, 20, 50.
\end{tabular}


confiscate Muslim properties in Western Thrace. ${ }^{64}$ Tahsin Ünal discusses a series of Greek laws which impede Western Thrace Muslims from buying land and other properties. ${ }^{65}$ Scholars such as Oran and Akgönül refer to how a possible re-allotment of land in Western Thrace would not be to the benefit of its Muslim population because it would leave them with small infertile allotments. ${ }^{66}$ Both scholars reply to their Greek colleagues, who argue that land reallotment in the Greek-Bulgarian border zone under military surveillance would put an end to arbitrary occupation of public properties by individuals which has occurred as a result of the gradual relaxation of the strict land regulations in the area. ${ }^{67}$

In an article published in the Greek newspaper Kathimerinē (Daily), Alexandrēs argues that the low educational level of Western Thrace Muslims is an element which characterises the nature of Turkish people, whether they live in Turkey or abroad. ${ }^{68}$ In his view, Turks follow traditional ways of life: they are emotionally attached to Muslim religious institutions and the land as a means of economic production. Within this context, the majority of Muslim farmers in Thrace, who in the article are implicitly thought of as Turks, show limited interest in higher education so that many of them remain farmers without any prospects for significant change in the future This view is not supported by the findings of later works which argue that by the end of the 1980s and the beginning of the 1990s an increasing number of Pomaks left their villages for urban centers in the region, where they worked mainly as builders. Also, at the same time a number of Muslims in the Komotēnē area were small business owners and merchants. ${ }^{69}$

\section{Press}

The Muslim press constitutes an important historical source for Greece's Muslims. The research of articles and news of political, social and cultural content could shed light on unknown aspects of their life. Yet, despite this there have been few works on Greece's Muslim press, with some of them not being published in Greek. Konortas provides a meticulous recording of the Muslim press in the Turkish language from

Merçil, 1979.

Ünal, 1970.

Oran, 1988; Akgönül, 1999.

Lambrianidēs, 1997.

Kathimerini (Greek newspaper), 21/5/1981.

Academy of Sciences, 1995; Petrakē, 1997. 
1898 to $1985 .^{70}$ Extracts from the Muslim minority press during the period of the Greek junta, 1967-1974, which are included in publications of the Türk Kültürü academic journal, have been published in Greek by the Greek academic journal Valkanikē Vivliografia. In the latter, the reader can also find an article of the Turkish scholar Selâhattin Yildiz which refers to the Muslim press of Western Thrace in the first years after the signing of the Lausanne Treaty. ${ }^{71}$ Iordanoglou refers to the press conflict between the anti-Kemalist conservatives (Palaiomousoulmanoi) and the reformists pro-Kemalist (Neoteristes) from the aftermath of the signing of the Lausanne Treaty to date and the gradual predominance of the pro-reformist group. Iordanoglou's work also provides a series of articles from Greek newspapers in Xanthēe, Komotēnē, Athens and Thessalonikē with reference to the Western Thrace Muslim minority. ${ }^{72}$ Along the same lines, Orhonlu's work which is published in Greek in the Deltion Tourkikēs Vivliografias refers to efforts made by Greeks, including the Greek press, to control the content of the Muslim press of Western Thrace. ${ }^{73}$

\section{Education}

Assēmakopoulou claims that the current educational regime of Greece's Muslims reproduces social differences and intensifies their introversion and marginalisation from the wider social environment in which they live. ${ }^{74}$ Yet, despite this and although minority education has been one of the thorniest minority problems, most of the academic works on the subject provide a rather general picture on this issue and do not discuss specific issues of Muslim education. Statistical information regarding the number of Muslim minority schools in western Thrace and the number of students and teachers can be found in many works. ${ }^{75}$ In his article, which has been translated in Greek, Erdogan discusses minority education from the mid 1930s to 1966 and argues that during those years the Greek authorities interfered with it by supporting the operation of minority religious schools, known as medresses, to the disadvantage of secular education, lest a Muslim intelligentsia was produced which could challenge state sovereignty in the region of western Thrace. ${ }^{76}$

\footnotetext{
$70 \quad$ Konortas, 1985.

71 Yildiz, 1979.

$72 \quad$ Iordanoglou, 1989.

73 Orhonlu, 1971.

$74 \quad$ Assimakopoulou \& Christidou-Lionarakē, 2002, p. 306.

75 Papaevgeniou, 1946; Academy of Sciences, 1995.

76 Merçil, 1971.
} 
There is little known about the teaching staff in the Muslim minority schools. Exceptions are the works of Panagiotidēs and Fragoudakē et. al, which refer to the categories of the teaching staff and the educational training they receive by the Greek state. ${ }^{77}$ Also, Stathi and Tressou refer to the functioning of the Special Educational Academy of Thessalonikē (Eidikē Paidagogikē Akadēmia Thessalonikēs), an educational institution which was founded by the Greek junta regime within Aristotle University of Thessalonikē in order to train teachers for the Muslim minority schools in Thrace. ${ }^{78}$ The objective behind that political move was to prevent the employment of teachers from Turkey in due time and thus reduce Ankara's interference with the minority educational affairs.

Poulēs, Tsitselikēs, and Baltsiotēs refer to the legal framework of the post-1923 Muslim minority education in Greece. ${ }^{79}$ As these scholars argue this framework was mainly set from 1952 to 1997. Tsitselikēs work, in particular, touches issues such as the foundation and functioning of the Muslim minority schools in the region, their status in comparison to the non-Muslim state schools, the appointment of their teaching staff and the management of their properties by the school authorities.

A number of academic works refer to the clash between the antiKemalist Palaiomousoulmanoi and the reformist Neoteristes around minority education affairs such as the teaching methods to be followed in minority schools. The clash was particularly fierce after 1928 with the introduction of educational reforms by the Kemalist regime in the Republic of Turkey. ${ }^{80}$ The high appeal of Turkish culture to many Muslim teachers, along with the import of school textbooks from Turkey, led to the gradual predominance of the reformist group in the clash over the minority's education. ${ }^{81}$

Article 41 of the Lausanne treaty provides for the members of the Muslim minority of Thrace to receive their elementary education in their mother tongue as well as in Greek. ${ }^{82}$ For reasons which have been explained elsewhere in this paper the Greek authorities forced all the ethnic elements of western Thrace Muslims to regard Turkish as their mother tongue and thus receive their education in that language.

\footnotetext{
77 Panagiotidēs, 1996; Fragoudakē et. al., 1997.

78 Stathē \& Tressou, 1997.

79 Poulēs, 1994; Tsitselikēs, 1996; Baltsiotēs, 1997, pp. 321-29.

80 Panagiotidēs, 1995; Tsitselikēs, 1996; Tsioumēs, 1994

81 Tsitselikēs, 1996.

82 Tsitselikēs, 1996, pp. 352-53.
} 
The deterioration of Greek-Turkish relations since the end of the 1960s led the Greek authorities to review this position. An increasing number of academic works appeared which researched the Pomak and Roma languages. Dictionaries and grammar books for the Pomak language were published, ${ }^{83}$ while academic interest was shown for the Muslim Romas as a distinct ethnic group with its own language. ${ }^{84}$

Vakalios et al., Stathē and others explore the curriculum, the teaching methods and the material used in the Muslim minority schools of western Thrace. ${ }^{85}$ They all agree that the textbooks for teaching of the Greek language best suit school students whose mother tongue is Greek and not the Muslim students of western Thrace for whom Greek is a second language with little or no use at home and their immediate environment. Sella-Mazē is among the few Greek scholars who have researched the Greek in use by the members of the western Thrace Muslim minority. Her research is mainly focused on Turkish-speaking Muslims. ${ }^{86}$ She argues that the use of Greek by Turkish-speaking members of the minority depends on a number of factors such as the environment in which they live and grow up, the working conditions of the teaching staff in the minority schools, the use of T.V. and the employment of the children in various agricultural activities. SellaMazē argues that the fact that the Turkish and Greek languages are quite different in terms of grammar, structure and vocabulary creates problems in the way that Greek is used as a second language. ${ }^{87}$

Dragōna uses methodological tools from the fields of psychoanalysis and social psychology in order to analyse the reactions of the teachers to new and revisionary knowledge which they are supposed to have in order to accept the ethnically, culturally, religiously and linguistically different students of the region. ${ }^{88}$ Dragōna's findings are based on her research over the educational programme Ekpaideuse Mousoulmanopaidōn (Education of Muslim Children) which has been in operation in western Thrace since May 1997. The programme has been under the auspices of the Greek Ministry of Education and Religions and its aim is to promote a smooth integration of Muslim children into Greek society by improving their performance in Muslim schools as well as their command of Greek language

\footnotetext{
$83 \quad$ Karachotza, 1995; Theocharidēs, 1996.

84 Zeginēs, 1994; Troubeta, 2001

85 Vakalios, 1997; Stathē, 1997.

$86 \quad$ Sella-Mazē, 1999

87 Sella-Mazē, 1994

88 Dragōna, 2004.
} 


\section{Conclusion}

As elsewhere in the Balkans, since its establishment as an independent state, Greece has sought to justify its existence in the name of a national myth which rejected the Ottoman Empire as a non-Greek political entity which had placed Greeks under a long-time 'yoke', had interrupted the glorious moments of their historical past and deprived them from benefiting from the cultural developments taking place in the 'civilized' world. The Ottoman Empire had condemned the Greeks to remain for a long time in cultural backwardness, which, since the time of their independence from Ottoman rule, they had sought to overcome and catch up with the cultural developments elsewhere in Europe - 'Greece's natural place' as many modern Greeks have liked to call it due to the fact that modern European culture claims rights upon Greek antiquity, which they see to form part of their cultural past.

The classification of Greece's Ottoman heritage as non-Greek is mainly founded on the fact that the established religion in the Ottoman Empire was Islam, which has been viewed as an alien cultural element to Modern Greek culture by the overwhelming majority of the country's political and cultural elites since its foundation in the 1830s. All Greek constitutions recognise Christian Orthodoxy as the established religion of the Greek state, while 'Greekness' has been defined in close relation to Orthodoxy, thus leaving little space for non-Orthodox people to be either seen or treated as Greeks. Within this context, the Muslims of Greece have been viewed as second class citizens by the Greek state and the majority of the Greek people and have been treated accordingly both in legal and practical terms. This is among others exemplified by the 1923 Greco-Turkish obligatory population exchange by which Athens agreed to exchange most of the country's Muslims for Orthodox people from the newly founded Republic of Turkey, who were regarded as Greek due to their religion.

The Greek academic elites have done little to change that view. The result is that the Muslims who have lived in Greece have been either silenced or at best badly represented for most of the Greece's modern history. The history of Greece's Muslims has to a great extent been distorted. We know little about the history of the Muslims who lived in the country prior to 1923, while for those who continued their lives in Greece after that year, the Muslims of western Thrace have monopolised academic interest. Until the beginning of the 1990s and to a lesser extend afterwards, this interest has been mainly expressed in close relation to the climate in Greco-Turkish relations. Publications 
have mainly occurred after periods of crises in bilateral relations and their subjects of discussion have been approached and analysed within the narrow prism of Greek-Turkish relations.

This picture has started to change since the beginning of the $1990 \mathrm{~s}$ with the publication of certain academic works, mainly by young scholars who have spent time undertaking their academic research and studies abroad. These scholars attempt either to emotionally detach their works from the political climate of the day in Greek-Turkish relations or to take part in it, but in an academically dispassionate way and by using analytical tools which extend far beyond their personal experiences and anguish to show that the Turkish territorial claims over western Thrace have been wrong. This situation has also been helped by changing political circumstances in Greece, in the Balkan region and internationally and by the activities of NGOs which have been particularly active in the country after the end of the Cold War. However, there is a lot to be done for a complete picture, a more objective story, to speak in the title's terms, of the Muslims of Greece to be produced. There are fields and subjects very little or totally unexplored, and those which have been explored often lack a complete conceptual framework for the reader to understand their analysis.

\section{References}

Academy of Sciences, $\bar{E}$ Anaptyxē tēs Thrakēs: Proklēseis kai Prooptikes (The [Economic] Development of Thrace: Challenges and Prospects), Athens: Academy of Sciences (Centre for the Study of Greek Society), 1995.

Akgönül, S., 'L' Emigration des Musulmans de Thrace Occidentale', Mésogeios, Vol. 3, 1999, pp. 31-49.

Alexandrēs, A., 'Exēnta Xronia Tourkikōn Paraspondiōn kai Proklēseōn: E Sēmasia tou Meionotikou Provlēmatos sto Plaisio tōn Ellinotourkikōn Diaforōn' (Sixty Years of Turkish Violations and Provocations: The Meaning of the Minority Problem within the Context of the GreekTurkish Disputes), Kathimerinē (Greek newspaper), 17,18,20, 21, 22 May 1981.

------------, 'To Istoriko Plaisio tōn Ellinotourkikōn Sxeseōn, 19231955' (The Historical Framework of the Greek-Turkish Relations, 1923- 
1955), in Alexēs Alexandrēs, Thanos Veremēs, Panos Kazakos, Vaggelēs Koufoudakēs, Christos Rozakēs, Giōrgos Tsitsopoulos (eds.), Oi Ellēnotourkikes Sxeseis, 1923-1987 (Greek-Turkish Relations, 1923-1987), Athens: Gnōsē, 1991a, pp. 31-172.

To Meionotiko Zētēma, 1954-1987 (The Minority Issue, 1954-1987), in Alexēs Alexandrēs, Thanos Veremēs, Panos Kazakos, Vaggelēs Koufoudakēs, Christos Rozakēs, Giōrgos Tsitsopoulos (eds.), Oi Ellēnotourkikes Scxeseis, 1923-1987 (Greek-Turkish Relations, 1923-1987), Athens: Gnōsē, 1991b, pp. 495-552.

Alexandrēs, A., Paresoglou, A., 'Mousoulmanoi tēs Ellēnikēs Thrakēs' (Muslims of Greek Thrace) in Thanos Veremēs (ed.), Valkania apo ton Dipolismo stē Nea Epoxē (Balkans from Bipolarity to the New Era), Athens: Gnōsē, 1995a, pp. 816-837.

'Mousoulmanoi tōn Valkaniōn kai Tourkia' (Muslims of the Balkans and Turkey) in Thanos Veremēs (ed.), Valkania apo ton Dipolismo stē Nea Epoxē (Balkans from Bipolarity to the New Era), Athens: Gnōsē, 1995b, pp. 838-874.

Andreadēs, K., Ė Mousoulmanikē Meionotis tēs Dytikēs Thrakēs (The Muslim Minority of Western Thrace), Thessalonikē: Etaireia Makedonikōn Spoudōn, Idryma Meletōn Xersonēsou tou Aimou (IMXA), 1956.

Asimakopoulou, F. \& Christidou-Lionarakē, S., Mousoulmanikē Meionotēta tēs Thrakēs kai oi Ellēnotourkikes Sxeseis, Athens: Livanē, 2002.

Aydinli, A., ' $\bar{E}$ Tragodia tēs Dytikēs Thrakēs' (The Tragedy of Western Thrace) (summary translation from Turkish conducted by $A$. Andreadēs), Valkanikē Vivliografia, Vol. 1, 1973, pp. 311-456.

Baltsiotēs, L., 'Ellēnikē Dioikēsē kai Meionotikē Ekpaideusē stē Dytikē Thrakē' (Greek Administration and Minority Education in Western Thrace) in Kōnstantinos Tsitselikēs and Dēmētrēs Christopoulos (eds.), To Meionotiko Fainomeno stēn Ellada: Mia Symvolē tōn Koinonikōn Epistimōn (The Minority Phenomenon in Greece: A Contribution to Social Sciences), Athens: Kritikē \& KEMO, 1997, pp. 315-348.

Bekiaridēs, G., Oi Muftēdes ōs Thrēskeutikoi Ëgetai tōn Mousoulmanōn tēs Periferias tōn kai ōs Dēmosia Arhē (Muftis as Religious Provincial Leaders and Public Authority), Komotēnē: [s.n], 1973. 
Bēkas, B., 'Nea Katastasē sta Notioanatolika Valkania' (New Situation in Southeastern Balkans), Anti, Issue No. 477, 18-10-1991, pp. 36-37.

Clayer, N., 'Islam, State and Society in Post-Communist Albania' in in Hugh Poulton \& Suha Taji-Farouki (eds.), Muslim Identity and the Balkan State, London: Hurst, 1997, pp. 115-138.

Coufoudakēs, V., 'To Kypriako, oi Ellēnotourkikes Sxeseis kai oi Yperdynameis, 1960-1986' (Cyrpus [Issue], Greek Turkish Relations and the Superpowers, 1960-1986), in Alexēs Alexandrēs, Thanos Veremēs, Panos Kazakos, Vaggelēs Koufoudakēs, Christos Rozakēs, Giōrgos Tsitsopoulos (eds.), Oi Ellēnotourkikes Sxeseis, 1923-1987 (Greek-Turkish Relations, 1923-1987), Athens: Gnōsē, 1991, pp. 215268.

Dōdos, D., Eklogikē Geografia tōn Meionotitōn. Meionotika Kommata stē Notio Valkanikē: Ellada, Voulgaria, Albania (The Electoral Behaviour of Minorities in Southern Balkans: Greece, Bulgaria and Albania), Athens: Exandas, 1994.

Dragōna, Th., Ekpaideuontas ton Anoikeio "Allo": To Paradeigma tēs Meionotikēs Ekpaideusēs (Educating the Unfamiliar "Other": The Case of Minority Education), Psychologia, Vol. 11, No. 1, 2004, pp. 20-33.

Economopoulos, C., La Minorite Musulmane en Thrace Occidentale, Athens: [s.n], 1967.

Eleftheriadēs, N., Oi Mousoulmanoi en Elladi (The Muslims in Greece), Athens: Petrakos, 1913.

------------, Ta Dikaia tēs Politeias epi tōn en Makedonia kai Ēpeirō Gaion (The Rights of the State on the Land Properties of Macedonia and Epirus), Athens: Raftanēs, 1915.

-------------, Gnōmodotiseis peri Ktēmatikōn Zētēmatōn kai Diaforōn en tais Neais Xorais (Consultatory Responses on Land Property Issues and Disputes in the 'New Areas'), Athens: Ethniko Typografeio, 1917.

Fragoudakē, A., Dragōna, Th., Androutsou, A., 'Diapolitismikē Ekpaideusē kai Epimorfōsē Ekpaideutikōn' (Inter-Cultural Education and Training of the Teaching Staff), Sygchrona Themata, Vol. 63, 1997, pp. 70-75. 
Georgoulēs S., O Thesmos tou Mouftē stēn Ellēnikē kai Allodapē Ennomē Taxē: Keimena Synthiko-Nomothesias (the Institution of the Mufti in the Greek and Foreign Legal Order: Documents on TreatiesLaws), Athens, Komotēnē: Sakkoulas, 1993.

Gerondopoulos, A., 'Anagaies Sygryseis gia tis Meionotites stēn Ellada kai Tourkia' (Necessary Comparisons for the Minorities in Greece and Turkey), Endoxora, Vol. 32, 1993, pp. 19-21.

Gialousēs, E., 'To Dimografiko Provlēma tēs Thrakēs' (The Demographic Problem of Thrace), Nea Ellopia, Vol. 2, 1996, pp. 32-34.

Iordanoglou, A., 'O Typos tēs Mousoulmanikēs Meinotētas tēs Dytikēs Thrakēs apo tē Synthēkē tēs Lōzannēs ōs Sēmera' (The Press of the Muslim Minority of Western Thrace from the Lausanne Treaty to Date), Valkanika Summeikta, Vol. 3, 1989, pp. 217-236.

Kadurgali, T., 'K.G. Andreadēs, Ē Mousoulmanikē Meionotis tēs Dytikēs Thrakēs (vivliokrisia)' (K.G.Andreadis, The Muslim Minority of Western Thrace (book review)), Valkanikē Vivliografia, Vol. 5, 1979, pp. 409410.

Kanakidou, E., 'To Diglōsso Analytiko Programma kai ē Parallēlē Didaskalia sta Mousoulmanika Sxoleia tēs Dytikēs Thrakēs' (The Bilingual Analytical Curriculum and the Parallel Teaching in the Muslim Schools of Western Thrace), Sygxronē Ekpaideusē, Vol. 89, No. 7-8, 1996, pp. 47-54.

Kēpouros, Ch., Den Theloume ē Thraki na Ginei Nea Kypros (We Do not Want Thrace to Become Another Cyprus), Athens: Pentadaktylos, 1989.

Konortas, P., 'La Presse d' Expression Turque des Musulmans de Grèce pendant la Période Post-Ottomane', Turcica, Vol. 17, 1985, pp. 245278.

Koppa, M., Oi Meionotētes sta Meta-kommounistika Valkania: Politikes tou Kentrou kai Meinotikes Apantēseis (Minorities in the PostCommunist Balkans: Policies of the Center and Minority Responses), Athens: Nea Sunora-A.A.Livanēs, 1997. 
Kotzagiōrgē, X., Panayotopoulou, A., Neoterē kai Sygxronē Istoria tēs Thrakēs: Vivliographikos Odēgos (Modern and Contemporary History of Thrace: A Bibliographic Guide), Thessalonikē: IMXA, 1993.

Kourtovik, G., 'Dikaiosynē kai Meionotētes' (Justice and Minorities) in Kōnstantinos Tsitselikēs and Dēmētrēs Christopoulos (eds.), To Meionotiko Fainomeno stēn Ellada: Mia Symvolē tōn Koinōnikōn Epistimōn (The Minority Phenomenon in Greece: A Contribution to Social Sciences), Athens: Kritikē \& KEMO, 1997, pp. 245-280.

Ladas, St., The Exchange of Minorities: Bulgaria, Greece and Turkey, New York: Macmillan, 1932.

Lambrianidēs, L., 'Topikē Anaptyxē kai Perioristikes Rythmiseis: H Periptōsē tēs Epitēroumenēs Zōnēs sta Xoria tōn Pomakōn tēs Xanthēs' (Local [Economic] Development and Restrictive Measures: The Case of the Zone of Surveillance in the Pomak Villages of Xanthi), Topos, Vol. 13, 1997, pp. 17-46.

Lithoxoou, D., 'Oi Gyftoi kai ē Istorikē tous Diadromē' (The Gypsies and their Historic Route), in D. Lithoxoou (ed.), Meionotika Zētēmata kai Ethnikē Syneidēsē stēn Ellada. Atasthalies tēs Ellēnikēs Istoriografias (Minority Issues and Greek (National) Consciousness in Greece. Irregularities of Greek Historiography), Athens: Leviathan, 1991a, pp. 83-95.

------------, 'Oi Gyftoi stēn Ellēnikē Vivliografia' (Gypsies in Greek Bibliography), in D. Lithoxoou (ed.), Meionotika Zētēmata kai Ethnikē Syneidēsē stēn Ellada. Atasthalies tēs Ellēnikēs Istoriografias (Minority Issues and Greek (National) Consciousness in Greece. Irregularities of Greek Historiography), Athens: Leviathan, 1991b, pp. 98-104.

Magriōtēs, G., Thrakē: $\bar{E}$ Epalxē tou Ellēnikou Vorra (Thrace. The Bastion of the Greek North), Athens: Risos, 1995.

Manolopoulou-Varvitsiōtē, K., Sygxrona Provlimata Meinotiton sta Valkania (Contemporary Minority Problems in the Balkans), Athens: Eirēnē, 1989.

Mavrogiannēs, D., 'Koinōniologikē Ereuna gia ta Paradosiaka Epaggelmata stē Thrakē kai to Voreio Aigaio kai gia tis Paradosiakes kai Perithoriakes Koinōnikes Omades stē Thrakē kai tē Makedonia' (Sociological Research for the Traditional Professions in Thrace and the North Aegean and the Traditional and Marginalised Social Groups in 
Thrace and Macedonia), Thrakikē Epetērida, Vol. 3, 1982, pp. 165174.

Merçil, E., 'To Ekpaideutiko Provlēma tōn Tourkōn tēs Dytikēs Thrakēs kai ē Ellēnikē Katapiesis' (The Educational Problems of the Turks of Western Thrace and the Greek Oppression), Deltion Tourkikēs Vivliografias, Vol. 12, 1971, pp. 37-43.

'To Zētēma tēs Afairesēs Edafōn apo ta Xeria tōn Tourkōn tēs Dytikēs Thrakēs' (The Issue of Confiscation of Land from the Hands of the Turks of Western Thrace), Valkanikē Vivliografia, Vol. 5, 1979, pp. 368-372.

Minaidēs, S., Ē Thriskeutikē Eleftheria tōn Mousoulmanōn stēn Ellēnikē Ennomē Taxē (The Religious Freedom of Muslims in the Greek Legal Order), Athens, Komotēnē: Sakkoulas, 1990.

Meinardus, Ronald, 'Muslims: Turks, Pomaks and Gypsies' in Richard Clogg (ed.), Minorities in Greece: Aspects of a Plural Society, London: Hurst, 2002, pp.81-93.

Nakos, G., To Nomiko Kathestos ton Teos Dimosiōn Othomanikōn Gaiōn, 1821-1912 (The Legal Status of the Former Public Ottoman Lands, 1821-1912), Thessalonikē: University Studio Press, 1984.

Nikolakopoulos, Ė., 'Politikes Dynameis kai Eklogikē Symperifora tēs Mousoulmanikēs Meionotētas stē Dytikē Thrakē: 1922-1955' (Political Powers and Electoral Behaviour of the Muslim Minority in Western Thrace: 1922-1955), Deltio Kendrou Mikrasiatikōn Spoudōn, Vol. 8, 1990-1991, pp. 171-204.

Notaras, G., 'Les Obstacles a I' Intégration des Musulmans de Trace' in Robert Bistolfi, François Zabbal (eds.), Islams d' Europe. Intégration ou Insertion Communautaire?, [La Tour d'Aigues]: Éditions de l'Aube, pp. 342-345.

Oran, B., 'La Minorité Turco-Musulmane de la Thrace Occidentale (Grèce)' in Semih Vaner (ed.), Le different Gréco-Turc, Paris: L' Harmattan, 1988, pp. 145-161.

Orhonlu, C., 'O Tourkikos Plythismos eis tēn Dytikēn Thrakēn' (The Turkish Population in Western Thrace), Deltion Tourkikēs Vivliografias, Vol. 6, 1969, pp. 19-48. 
--.--------, 'Ē epi tou Tourkikou Typou tēs Dytikēs Thrakēs Askoumenē Piesēs' (The Pressure Exercised on the Turkish Press of Western Thrace), Deltion Tourkikis Vivliografias, Vol. 12, 1971, pp. 4548.

Panagiotidēs, N., Mousoulmanikē Meionotēta kai Ethnikē Syneidēsē (Muslim Minority and National Consciousness), Alexandroupolē: Topikē Enōsē Dimōn kai Koinotētōn Nomou Evrou, 1995.

---------------To Meionotiko Ekpaideftiko Systēma tēs Elladas (The Minority Educational Systems of Greece), Alexandroupolē: Gnōmē, 1996.

Papachristodoulou, P., Oi Pomakoi kai o Dikaios Agōnas tōn $n^{\prime}$ Apallagoun apo ton Dysvastachto Voulgariko Zygo (The Pomaks and their Fair Struggle to Get Rid off the Unbearable Bulgarian Yoke), Athens: Etaireia Thrakikōn Meletōn, 1947.

Papaevgeniou, A., Voreios Ellas: Meionotētes apo Statistikēs Apopseōs en Sxesei me ton Plythismon kai tēn Ekpaidefsin (North Greece: Minorities from a Viewpoint in Relation to the Population and Education), Thessalonikē: Sullogos pros Diadosēn tōn Ellinikōn Grammatōn, 1946.

Papathanasi-Mousiopoulou, K., 'Ptyxes apo tēn Istoria tōn Pomakōn tēs Dytikēs Thrakēs' (Apects from the History of Pomaks of Western Thrace), Thrakikē Epetērida, Vol. 8, 1991, pp. 229-238

Pentzopoulos, D., The Balkan Exchange of Minorities and Impact upon Greece, Paris, Hague: Mouton, 1962.

Perrakēs, S., 'Oi Meionotētes stē Metapsyxropolemikē Epoxē: Ellēnikes kai Diethneis Diastaseis' (Minorities in the Post-Cold War Period: Greek and International Dimensions), interview in Thessalonikē (Greek newspaper), 25-5-1993.

Petrakē, G., 'Stēn Xanthē kai sto Lavrio' (In Xanthi and Lavrio), Sygxrona Themata, Vol. 63, 1997, pp. 84-85.

Popovic, A., L'Islam Balkanique. Les Musulmans du Sud-Est Européen dans La Période Post-Ottomane, Berlin: Harrassowitz (Balkanologische Veröftentlichungen, 11), 1986. 
Poulēs, P., 'To Nomiko Plaisio Leitourgias tōn Meionotikōn Sxoleiōn stē Dytikē Thrakēe' (The Legal Framework of Minority Schools in Western Thrace), Dioikitikē Dikē, Vol. 5, 1994, pp. 1001-1017.

Poulton, H., The Balkans: Minorities and States in Conflict, London: Minority Rights Publications, 1993.

------------, 'Turkey as a Kin-State: Turkish Foreign Policy towards Turkish and Muslim Communities in the Balkans' in Hugh Poulton \& Suha Taji-Farouki (eds.), Muslim Identity and the Balkan State, London: Hurst, 1997, pp. 194-213.

Rozakēs, Ch., 'To Diethnes Nomiko Kathestōs tou Aigaiou kai ē Ellēnotourkikē Krisē: Ta Dimerē kai ta Diethnē Thesmika Zētēmata' (The International Legal Status of the Aegean [Sea] and the GreekTurkish Crisis: Bilateral and International Legal Matters) in Alexēs Alexandrēs, Thanos Veremēs, Panos Kazakos, Vaggelēs Koufoudakēs, Christos Rozakēs, Giōrgos Tsitsopoulos (eds.), Oi Ellēnotourkikes Sxeseis, 1923-1987 (Greek-Turkish Relations, 1923-1987), Athens: Gnōsē, 1991, pp. 269-492.

------------, 'Ethnikismoi kai Meinotētes sta Valkania: Evropaikes Apopeires gia ton Kateunasmo (tōn Prōtōn) kai tin Prostasia (ton Defteron)' (Nationalisms and Minorities in the Balkans: European Efforts to appease (the former) and protect (the latter)) in Sotērēs Dalēs (ed.), Evropaikē Enopiēsē kai Valkanikē Polydiaspasē (European Integration and Balkan Fragmentation), Athens: Siderēs, 1994, pp. 163-182.

Sella-Mazē, H., 'La Minorité Turcophone Musulmane du Nord-Est de la Grèce et les Dernières Évolutions Politiques dans les Balkans', Plurilinguismes, Vol. 4, 1992, pp. 203-231.

------------, Stoicheia Antiparavolikēs Grammatikēs Ellēnikēs-Tourkikēs (Elements By Comparing the Greek and Turkish Grammars), Athens: Organismos Ekdoseōn Didaktikōn Vivliōn, 1994.

Soltaridēs, S., Tourkika Sxolika Vivlia: Ideologikes Kateuthynseis kai Politikos Prosanatolismos. Meletē-Erevna (Turkish School Textbooks: Ideological Directions and Political Orientation. Research-Study), Athens: Estia, 1986. 
---.--------, E Istoria tōn Moufteiōn tēs Dytikēs Thrakēs (The History of the Muftis Offices of Western Thrace), Athens: Nea Synora- A.A. Livanēs, 1997.

Stathē, P., 'Ta Tourkika Sxolika Egxeiridia stē Thrakē' (The Turkish School Textbooks in Thrace), Sygxrona Themata, Vol. 63, 1997, pp. 65-67.

Stathē, P., Tressou, E., 'Ē Tritovathmia Meionotikē Ekpaideusē' (Higher Minority Education), Sygxrona Themata, Vol. 63, 1997, pp. 68-9.

Troubeta, S., Katastevazontas Taftotētes gia tous Mousoulmanous tēs Thrakēs: To Paradeigma tōn Pomakōn kai tōn Tsigganōn (Constructing Identities for the Muslims of Thrace: The Case of Pomaks and Gypsies), Athens: Kritikē \& KEMO, 2001.

Tsibiridou, F., 'E Ethnologikē Ereuna $s$ ' ena Chōrio tēs Oreinēs Rodopēs: Symvolē stē Meletē tōn Syggenikōn Desmōn' (Ethnological Research in a Village of Mountainous Rhodopi: A Contribution to the Study of Family Relations), Thrakikē Epetērida, Vol. 6, 1985-86, pp. 213-223.

'Choros: Domes kai Anaparastaseis. Anthropologikē Protasē Anagnōsēs tou Chorou sta Pomakochoria tou Nomou Rodopēs' (Space: Structures and Representations. Anthropological Proposition for Reading the Space in the Pomak Villages of the Rhodopi Prefecture), Ethnologia, Vol. 3, 1994, pp. 5-31.

'E Ethnikistikē Ideologia stis Syllogikes Anaparastaseis: Emfylioi Roloi kai Sexoualikotēta mesa apo to Logo tōn Politistikōn Foreōn mias Akritēs Polēs' (The National Ideology in Public Images: Gender Roles and Sexuality through the Wording of the Cultural Societies of a Bordering City', Dinē, Vol. 8, 1995-1996, pp. 153-179.

-------------, 'Processus de Modernisation et de Marginalisation: Les Cas d' Une Minorité' in Actes de deux Journées de Travail sur la Transition: Les Mechanismes de la Transition dans $L^{\prime}$ Europe des Transformations, Athens: Sakkoulas, 1996, pp. 53-70.

-------------, 'Esquisse d'une Problématique sur la Construction des identities dans la Région Montagneuse du Rhodope en Grèce', Ethnologia Balkanica, Vol. 2, 1998, pp. 185-195. 
-------------, Les Pomak dans la Thrace Grecque. Discours Ethnique et Pratiques Socioculturelles, Paris, Montreal: L' Harmattan, 2000.

Tsitselikēs, K., To Diethnes kai Evropaiko Kathestōs Prostasias tōn Glossikōn Dikaiomatōn tōn Meionotētōn kai ē Ellēnikē Ennomē Taxē (The International and European Regime for the Protection of Linguistic and Minority Rights in the Greek Legal Order), Athens and Komotēnē: Sakkoulas, 1996.

----------------, 'Ē Thesē tou Mouftē stēn Ellēnikē Ennomē Taxē' (The Status of Muftis in the Greek Legal Order) in Dēmētrēs Christopoulos (ed.), Nomika Zētēmata Thrēskeutikēs Eterotētas stēn Ellada ((Legal Issues of Religious Difference in Greece), Athens: Kritikē \& KEMO, 1999, pp. 271-330.

Tsitselikēs, K., Christopoulos, D., 'O Entopismos tou Meionotikou Fainomenou stēn Ellada apo tē Nomikē Epistēmē kai to Dikaio' (The Localization of the Minority Pheonomenon in Greece by the Science of Law and Justice) in Kōnstantinos Tsitselikēs and Dēmētrēs Christopoulos (eds.), To Meionotiko Fainomeno stēn Ellada: Mia Symvolē tōn Koinōnikōn Epistimōn (The Minority Phenomenon in Greece: A Contribution to Social Sciences), Athens: Kritikē \& KEMO, 1997, pp. 415-461.

(eds.), To Meionotiko Fainomeno stēn Ellada: Mia Symvolē tōn Koinōnikōn Epistēmōn (The Minority Phenomenon in Greece: A Contribution to Social Sciences), Athens: Kritikē \& KEMO, 1997.

Tsitsopoulos, G., Veremēs, Th., 'Ellēnotourkikes Amyntikes Sxeseis, 1945-1987' (Greek-Turkish Defence Relations, 1945-1987), in Alexis Alexandris, Thanos Veremis, Panos Kazakos, Vaggelis Koufoudakis, Christos Rozakis, Giorgos Tsitsopoulos (eds.), Oi Ellēnotourkikes Sxeseis, 1923-1987 (Greek-Turkish Relations, 1923-1987), Athens: Gnōsē, 1991, pp. 173-214.

Ünal, T., 'Oi Tourkoi tēs Dytikēs Thrakēs' (The Turks of Western Thrace), Deltion Tourkikēs Vivliografias, Vol. 9, 1970, pp. 11-16.

Vakalios, Th., Kanakidou, E., Panagiotidēs, N., To Provlima tēs Diapolitismikēs Ekpaideusēs stē Dytikē Thrakē. $\bar{E}$ Periptōsē tēs Mousoulmanikēs Meionotētas me Emfasē stou Pomakous: Erevna (The Problem of Bicultural Education in Western Thrace: The Case of the 
Muslim Minority with Emphasis on the Pomaks: Research), Athens: Gutenberg, 1997.

Vakalopoulos, K., 'The Muslim Minority in Western Thrace', Kathimerinē (Greek newspaper), 3 February 1990.

Voss, Ch., 'Language Ideology between Self-Identification and Ascription among the Slavic-Speakers in Greek Macedonia and Thrace' in Herausgegeben Von, Klaus Steinke, Christian Voss (eds.), The Pomaks in Greece and Bulgaria, München: Verlag Otto Sagner, 2007, pp. 177-192.

Voulgarēs, G. et al.,'É Prolēpsē kai ē Antimetōpisē tou 'allou' stēn Sēmerinē Ellada. Porismata Empeirikēs Ereunas' (The Perception and Dealing with the 'Other' in Today's Greece: Findings of Empirical Research), Elliniki Epitheorisi Politikis Epistimis, Vol. 5, No. 4, 1995, pp. $81-100$

Charalampidēs, A., 'Oi Pomakoi tēs Rodopēs' (The Pomaks of Rhodopi), Thrakikē Epetērida, Vol. 6, 1985-86, pp. 88-97.

Xyrotyrēs, N., 'Achrianes kai Pomakoi: Thrakes ē Slavoi?' (Achrianes or Pomaks: Thracians or Slavs?) in Praktika B Symposiou Laografias tou Voreioelladikou Chōrou (Ëpeiros-Makedonia-Thrakē), Komotēnē, 19-22 Martiou 1975 (Proceedings of the $2^{\text {nd }}$ Symposium of Folklore Studies of Northern Greek Space (Epirus-Macedonia-Thrace) in Komotēnē, 19-22 March 1975, Thessaolonikē: IMXA, 1976, pp. 333-358.

Yildiz, S., 'O Mehmet Hilmi pou Anapse tē Floga tou Tourkikou Ethnikismou stē Dytikē Thrakē, kai o Tourkikos Typos stē Dytikē Thrakē' (Mehmet Hilmi who Set the Fire of Turkish Nationalism in Western Thrace and the Turkish Press in Western Thrace), Valkanike Vivliografia, Vol. 5, 1979, pp. 373-378.

Zeginēs, E., O Bektasismos stē D. Thrakē: Symvolē stēn Istoria tēs Diadoseōs tou Mousoulmanismou ston Elladiko Chōro (Bektashism in Western Thrace: Contribution to the History of the Diffusion of Islam in Greece), Thessalonikē: IMXA, 1988.

------------, Oi Mousoulmanoi Athigganoi tēs Thrakēs (The Muslim Tsiganoi (Romas) of Thrace), Thessalonikē: IMXA, 1994. 